\title{
DEVELOPMENT POLICIES AND PARTNERSHIPS IN SOUTHERN EUROPE: EVIDENCE FROM VARNA AND BARI ${ }^{1}$
}

Theodore METAXAS 2

\begin{abstract}
The aim of this research is to investigate through empirical and primary data the possibility of design and implementation of development policies and partnerships in the South Eastern Europe especially in the areas of Bari and Varna. Specifically, this research is based on data extracted from 183 SMEs firms of all the productive sectors which express their evaluations for the role of specific development policies to their competitiveness per sector but also the degree and dynamic of developing partnerships with the local and regional authorities. Further the findings of the analysis designate the important issues of regional economic development focusing on the ability of public authorities to design and implement effectively development policies in order to benefit the competitiveness of themselves and the firms as well as the special sensitive areas of Southeastern Europe which is a very interesting zone for research.
\end{abstract}

Key words: Development Policies, partnerships, empirical research, South Europe, Varna, Bari

Jel: O18, R50, R58

\section{Introduction: Define the role of Local Authorities in partnerships and economic development}

Over the recent years, Europe is being identified by the rapid procedures towards its completion (Eriksen, 2004; Caporaso, 1996). In the frame of the new politicaleconomic setting, European cities are invited to square with the growth standards and exploit the challenges and opportunities that appear in not only international but also in local level aiming the distinction and support of their benefits (Marks and McAdam, 1996; de Rooij, 2002; Crossa, 2009; Pereira and Coutinho, 2011). The main priority of planning and developing strategies focuses on the viable development of the local societies with an emphasis on more than just the economic development, since the existence of local authorities with entrepreneurial orientation derives as a basic need, mainly in the '90s (van den Berg and Braun, 1999). For many scholars these development strategies entail transforming the image and functions of cities from centres of production and work to attractive places for local and global investment (Cochrane and Jonas, 1999; Metaxas, 2011a). Moreover, a number of

\footnotetext{
1 Acknowledgement: This research constitutes a part of a wider research under the title 'Local Economic Development and Cities Competition in Southeastern Europe' in the frame of 'HERACLITES: Studies in Basic Research'. The project is co-funded by the European Union European Social Fund \& National Resources - EPEAEK II. The financial support of these organizations and the contribution of the Polytechnic Schools of Varna and Bari are greatly acknowledged

2 Theodore Metaxas, Assistant Professor, Department of Economics, University of Thessaly, 43 Korai Str, 38 333, Volos, Greece, Tel: ++30 24210 74917, Fax: ++30 24210 74772, Email: metaxas@econ.uth.gr
} 
recent studies award the significance of organizing capacity as an important factor on development process locally (Kresl and Singh, 1999; Polidano, 2000; van den Berg et al., 1997, 2003). Van den Berg et al's studies $(1997,1999)$, showed that the most important factors for the formation of organizing capacity in the planning and implementation of policies, are the clear definition of city vision, the capacity for strategic networks development and, finally, leadership.

Worrall et al., (1998), referring to the operational practices of UK local authorities, supported that a strategic approach can be enacted in a 'revealed' sense, or an implicit sense without the panoply of formal strategy documents. They also observe, however, that some organisations which espouse a strategic approach do not reflect it in their operational practices. It is just too easy to go through the motions of strategic policy and planning without operationalising plans so that they shape culture, actions and decisions large and small (Scott et al., 2004). Cheshire and Magrini $(1999,2001)$ examine the role of local policies and their influence on region development and conclude that the ability of effective development policies on local level, mainly of the strategies for local development promotion policies, is not a random procedure but it is related with a number of factors the commonest of which is the structure of the local authority - or the administrative ability.

A number of older and recent studies, award the significance of development partnerships between the public and private sector (Sellgren, 1990; Smallbone, 1991; Dicken et al,. 1994; Fuller et al., 2003; Metaxas, 2010). The promotion of sustainable urban development and the implementation of the partnership principle are two complementary, mutually reinforcing goals of EU policies aiming at successful urban governance (Getimis and Grigoriadou, 2004). In addition, partnerships are vital to any sustainable redevelopment program because they foster communications and the building of cooperation and trust between relevant stakeholders. Groups such as community development organizations, chambers of commerce, or business councils can contribute to the process of local economic development (Dekker and van Kempen, 2004).

Furthermore, Bennett and Krebs (1991, p.21), approaching the relation between firms and local authorities mention the creation of 'entrepreneurial agents' which will manage and control the available resources and sort out the priorities in firms' actions with one another and with other public and business actors. A relevant argument that focused on the efficient use of the existing resources, has been expressed more recently by Wallis and Dollery (2002) and Drever (2006), while Giacchero et al. (2007, p.173, cited in Cantner and Malerba 2007), supported that relationships between agents, and between agents and institutions in local level, become an important element in the creation of dynamic competitive advantages, based on the formation, transmission and evolution of knowledge. More recently, Hagedoorn et al. (2000) awarded the establishment of partnerships between local authorities and higher education institutions and research centers. Scott et al. (2004, p.12) in the frame of 'Local Futures' project, supported that the new strategic policy and planning environment requires local governments to share power with other public and private organisations, while in a very recent study regarding the factors that influencing SMEs competitiveness in Western Region of Romania, Bibu et al., (2008) find that the governmental and states institutions have an important role in firms activities, considering that government and non government organizations can 
be more involved in consulting activities, training, creating a favourable environment for small and medium business, while the most important communication channel between firms and government are county organizations for SME's, chambers for industry and trade

All the above factors lead to the seeking of those groups in the city environment which, having the desire and also the knowledge, will act strategically towards the organizing of planning and the successful implementation of the chosen competitiveness policies (Cheshire and Magrini, 1999; Polidano, 2000).

The above brief review leads to the conclusion that the partnerships between groups which are part of the group for the development and competitiveness procedures on local level have a positive contribution to the growth and prosperity. Naturally, the representation of a common vision and goals or interest is something complicated and multidimensional. The most important factor is the ability and dynamic of local authorities to design and implement development policies and activities with the regional and local community in order to be insured and checked the development procedure.

Exactly at this point this research focus and investigates the importance of specific development policies for the development of firms in two cities of medium size $^{3}$ in South Eastern Europe, Varna in Bulgaria and Bari in Italy. The added value of this research is important taking in account the fact that there is a lack of similar researches on local level as well as on this geographical zone of the South Eastern Europe. Several representative researches come from Javier Santos-Cumplido and Linan (2002) on firms and business men of Sevil in Spain, and Metaxas and Kallioras (2007) on firms in the urban dipole of Larisa and Volos in Greece and firms in other cities of Balkans (Tirana, Sofia, Thessaloniki) [RIMED, 2007], or comparative production sectors analysis of southeastern cities (Metaxas, 2011b) Also this research raise important issues and questions about local development since it presents directly the evaluations and views of a large number of local firms which have a clear view for local communities and economies.

Finally, this research apart from presenting a satisfied image of the inner environment of the development of the two cities it also provides findings that could lead to evaluation, design, implementation or rejection and reconstruction of specific actions and policies locally. This research uses statistical analysis to group the importance of these policies for firms per production sector while also designates which policies are more important for the development of the city. The analysis also examines the degree of effect of these policies to the competiveness of firms as well as the degree of partnerships created among firms and the local authorities and in which policies fields. The structure of this paper is the following: The next section describes the methodology and the third section analyzes the profile of cities, firms and local authorities of the studied cities. In the fourth section the findings of the research are presented and answers are given to the raised questions while the fifth section concerns the conclusions of this research.

3 Medium-size cities are considered those with a population between 100.000 and 300.000 residents (EC, 1996:155 - Eurostat). Lavergne and Mollet (1991), consider medium-size cities to be those with a population from 100.000 to 500.000 people, while Atkinson (1999), those with a population between 50.000 and 250.000 residents. 


\section{Methodology and research questions}

As study cities were used Varna (Bulgaria) and Bari (Italy). These cities were chosen by taking into account some common characteristics. Specifically: a) they belong to the Objective 1 regions of $\mathrm{EU}, \mathrm{b})$ are medium-sized cities (300.000$500.000)^{i}$ residents, c) because of their geographical position, both of them are important ports in their countries, d) they are located far away from the EU decision centers, namely, on the zone of Southeastern Europe - Balkans and e) the research was funded by the European Union - European Social Fund \& National Resources EPEAEK II, and these cities accepted to participate in this project.

Research has been done with the collection of primary data from 183 firms from all production factors (manufacture, commerce, services and tourism). 96 of these firms located in Bari and 87 in Varna. More specifically, the characteristics of the research are the following: a) Research took place from May, 2006 to June, 2008 through the use of questionnaires and personal interviews, b) the questionnaire includes open-closed questions in five groups of questions, for the answers ranking scale was used (1-10) [Stathakopoulos 2005, p.134], c) each interview lasted 25 to 45 minutes, d) $90 \%$ of the firms had over 20 employees, e) 85,4\% were local, f) research took place in cities core and up $50 \mathrm{~km}$ outside them, g) interviews were made with high level managers and also business-owners, h) each interview was certified with the signature of the responder who filled in the questionnaire and the business stamp and i) the selection of the firms was based on data that the Commercial and Industrial Chambers of Bari and Varna.

\section{Cities, Firms and Local Authorities Profiles}

The region of Varna (figure 1) is located in the northeast part of Bulgaria; it has an area of $3820 \mathrm{~km}^{2}$ and is an 'entrance gate' to the Black Sea. The city of Varna has a population of 343.000 residents and is the third biggest city in Bulgaria. The production profile of the city and its surrounding area is composed of metallurgy and machinery businesses, shipyards, chemical industries, shipping lines as well as of food industries, textiles factories and construction companies.

Figure 1: Varna's location in Bulgaria

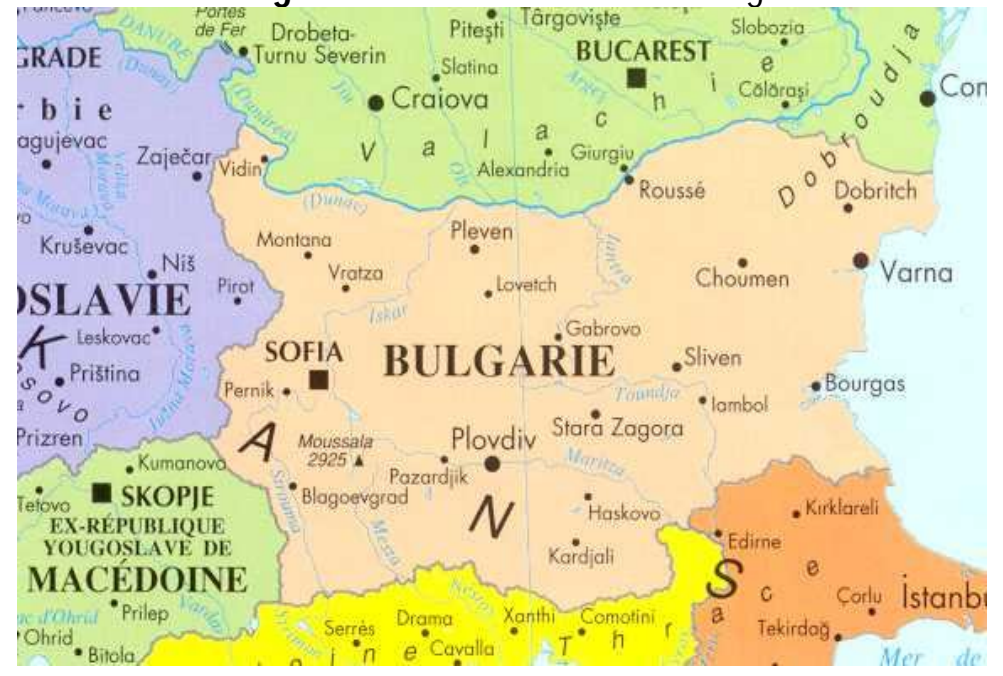


On the other hand, Bari (figure 2) is located in the region of Puglia, on the south cost of the Adriatic Sea and is the second most important city of South Italy, after Naples, with a population of almost 312.000 residents. The traditional production sectors concern the manufacturing of agricultural and sea products. In addition the production structure of the city is composed of commercial firms, service businesses, soft industrial sectors (textiles, leather etc.) and automobile industries (Waters, 1999). A significant role in firms' competitiveness has the port of Bari which connects Italy with Greece. In addition, Bari possesses a first class knowledge infrastructure, which is uncommon in Southern Italy. Secondly, the city is oriented towards services, which makes it a real economic capital within the Mezzogiorno, a "Southern Milan". Bari is also a historical, monumental city, whose medieval walled centre has been recently regenerated with funds from the URBAN programme of the European Commission (van Winden and Woets, 2003).

Regarding the profile of the studied firms, $54,1 \%$ of them belongs to the industrial/ manufacture sector, $23,5 \%$ to the commercial sector, $12,0 \%$ to the services and $10,4 \%$ to the tourism sector. $85,4 \%$ of them are local - something that means that the appreciation of firms is extremely important, since they are aware of the urban environment (weaknesses and strengths) as well as of the development policies applied by the local authorities, as much for the benefit of the cities as for the benefit of the businesses themselves. Furthermore, concerning the number of employees the average is 85,6 employees (year 2006). The studies firms are small-medium firms in total.

Figure 2: Bari Location

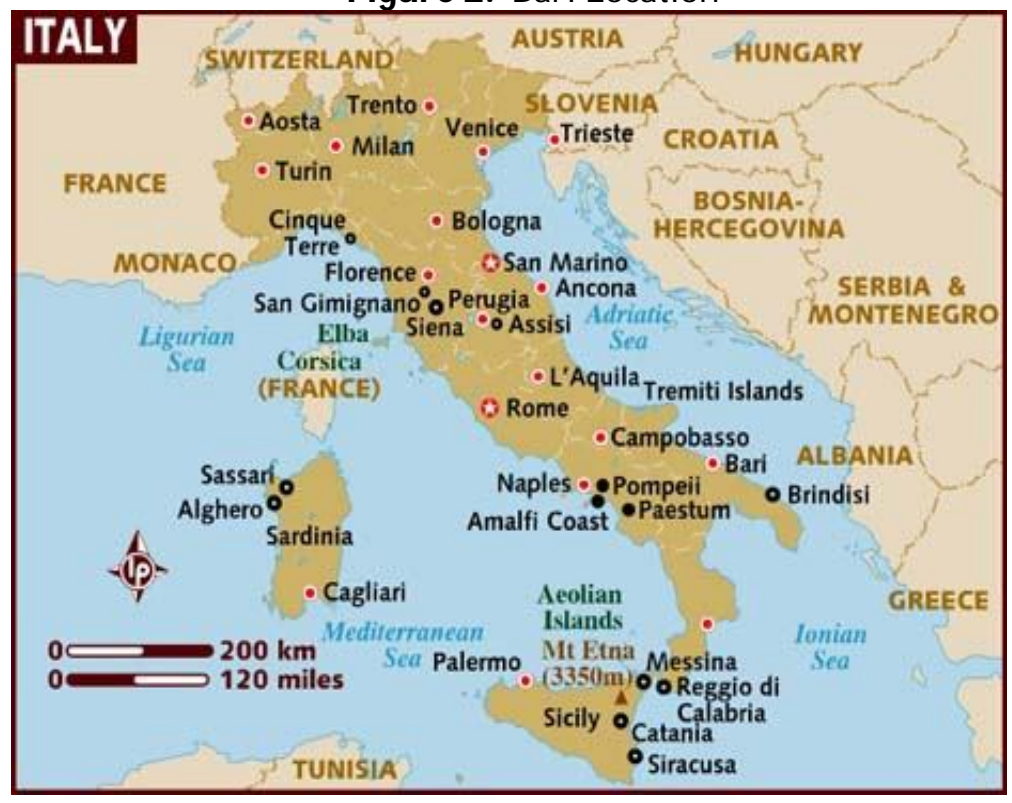

Finally, shaping the profile of Local Authorities of the studied areas, in the case of Varna, the period of the last twenty years, after 1992, was for all the cities in Bulgaria a time full of challenges and changes, characterized by the need on the part of the cities to obtain an effective local administration and management, in order to become more able to compete for the attraction of investments with other cities both on national and international level (LGI, 2003). Since 1999, the cities of Bulgaria are 
forced to adopt a city development strategy (CDS) which constitutes the base for a long term development strategy (Tsenkova, 2004; Driscoll, 2002), while in 2003 Local Government Initiative, planed a series of development policies in order to improve the effectiveness of City Councils (Robison, 2003). For the first time, the Municipality is the basic administrative actor and local authorities have to reconstruct and become oriented towards certain changes such as the acquisition of technical know how and practical experience or the development of relations and co-operations with the private sector (Kapitanova and Minis, 2003). As a consequence, the East European countries, and Bulgaria in this case, in the frame of the transition and adaptation period they run, are found in a very important stage of reconstruction of the role their local authorities are asked to play. As a result, their degree of experience, knowledge and actions lies on a low level. Focusing on the city of Varna, its seems important to mention that in October of 2004 the city of Varna was awarded with the first prize as the Best European City of the Future 2004-2005 in the Category «South-East Europe» during the Annual Competition of FDI Magazine, jointly with the Financial Times. Furthermore, in the frame of Local Authorities action, the city participated in the project "Lightning Rehabilitation and Promotion of Varna Sea Garden and Its Tourist Attractions", Budget line BG BG2003/ 004-937.11.03 PHARE Program - Economic and Social Cohesion (Dec., 2005 - Dec., 2006), in order to improve the tourist attractiveness and promotion of Varna as a modern European destination for tourists from all over the world. Project includes the three main groups of activities: a) Rehabilitation of Varna Sea Garden lightening facilities with a focus on installation of energy saving lamps and an effective illumination; b) Renovation of the building and collections of the National Sea Museum, located in the Garden, and c) Support and promotional activities concerning further development of the tourism in the region.

On the other hand the profile of local authorities in Italy is different. Forty years ago Pacione (1976) stated that regions in Italy suffering from a high dependence on ageing industries are usually identified by a traditionally slow rate of economic growth and high levels of unemployment. In our days, the significance of regions and municipalities on local development process is crucial. According to heading $\mathrm{V}$ of the Italian Constitution "Regions, Provinces, Municipalities", Italian Regions have exclusive competence on issues affecting territorial development (tourism, industry, trade and so on) [Cantoro, 2007]. During the last years, the question concerning local development has been largely debated in Italy and the need to give a concrete implementation to the development policies it has been ratified at national level. According to EU $5^{\text {th }}$ Framework Programme, Italian society and politics is so strongly associated with local government that we tend to speak of "regions made up of municipalities" (Diamantini, 2004). Municipality governments had always been the core of the Italian decentralization system, having their own structure and operation, being responsible for the planning and the implementation of municipal policies (transportation, zoning, social services, sanitation e.t.c.) [Piperno, 2000; CoR Studies, 2004], while, during the last decade their frame of jurisdiction expanded covering a broader range of policies such as: the allocation of industrial incentives, public works (except for motorways), education, heritage and environment conservation (Piperno 2000). Meanwhile, Italy as a member-state of E.U., reinforced - through European projects - the regions of Target1 (South Italy, Mezzogiorno), contributing to their development. 
According to a number of studies the recently-introduced policies for the Mezzogiorno have set out in very different ways to foster local development especially in comparison with the Italian North (D'Antonio et. al., 1988; Barca and Pellegrini, 2000; Viesti, 2002; Loddo, 2004; Calafati, 2005; Daniele, 2009). According to Viesti (2002), following the reform (1988) of the European Structural Funds, the regional administrations of the Italian south were called upon to draw up multi-year programmes - that is, coordinated and coherent sets of measures to structurally alter the region's economic circumstances-they were faced by a task that was entirely new to them. Managing such measures, too, was an entirely new experience, and the extraordinary slowness with which policies were implemented was the consequence.

On the other hand, the role of local governments within the 'Third Italy' notion was crucial, mainly in supporting the development of a modern small industry and in shaping its cooperative nature (Warren, 1994: 98 cited in Waters, 1999; Rossi, 2004). Furthermore, the local representation of interests that provided through decentralized institutions is a major factor in local economic performance (Bagnasco and Sabel, 1995).

It's important to mention that initiatives that take place the recent years in Italy and the region of Puglia contributed to setting up innovative projects of particular territorial and environmental significance, in collaboration with local authorities and within the regional planning framework. Especially in the case of Bari, particular development initiatives have been taken places in order to enforce the local development process. For instance, the URBAN II Mola di Bari Programme that is based on an integrated approach combining physical and socio-economic interventions.

Its strategy is based on actions aimed to renew buildings and open areas, environmental infrastructure (e.g. water purification), natural and cultural heritage. Moreover, the URBAN II Mola di Bari Programme supports small and medium enterprises (SMEs) and the development of the harbour. Furthermore, many interventions concern the enhancement of the tourism sector and local crafts in order to implement new services and stimulate tourism and cultural activities. These actions promote the enhancement of social economy, social services and training to facilitate access to the labour market for disadvantaged groups (EUKN, 2009).

In conclusion, we support that in Italy local authorities constitute the oldest administrative entity with clear orientation of its role and jurisdiction, something that in the case of Bulgaria was something unknown, till recently. In the case of Bulgaria the reconstruction of the political and administrative infrastructure, in the frame of a difficult adaptation to the new norms of the E.U., was based more on reliability and less on a well established experience and it started in the beginning of the 90s (Kapitanova and Minis 2003). In Bulgaria, the economic and political changes had to take place simultaneously, taking into consideration the fact that there was no political experience in the taking of development actions under the conditions of the new European environment. The two countries belong to different political, economic, social and cultural environments. Italy is traditionally a great power in Europe ${ }^{4}$ while Bulgaria is just stepping onto the threshold Europe. These differences are crucial and

4 In the case of Italy these picture stands only for the economically strong North, since the South presents a different, economically weaker profile. 
consequently influence the environment of these three countries in different ways. As a result, all the production forces which act and operate in the internal environment of their regions and cities are influenced, too.

\section{Selection of development policies}

Viesti (2002), supported that the purpose of policies for local development is to increase the economic development, employment and productivity, and to improve the living standards and life quality, of a group of citizens and of enterprises located in a specific geographical area. Several studies (Harvey 1989, Strange 1997, Hall and Hubbard 1998, Priemus 2002; Margassi, 2004) the effectiveness of development programs/ policies for cities and micro regions is often hindered by the limited capacity of municipal governments. We saw previously, that also in study areas and especially in Bari, planned and developed policies and actions mainly based on the support and EU programmes. Taking this fact under consideration, the selection of the specific policies was made with special care so that the will cover a wide range of cooperations in fields such as joined actions between private and public sectors, cooperations with higher education institutes, the implementation of strategic planning methods, actions concerning the development of connection networks with other cities on European level, as well as actions pertaining to the social and entrepreneurial environment of cities. It is important that the specific development policies comply with the E.U. principles towards the reinforcement of competitiveness of its regions, with main development axis the co-operation between local/ regional administrations and firms for the planning and the implementation of selected actions (European Communities, 2003).

More specifically, reference is made concerning promotion policies for the cooperation with the private sector in specific development projects (e.g. support of the local industry with characteristic cases of various regions, [Hudiksvall (Sweden),

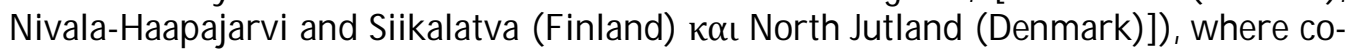
operations were planned and implemented aiming at the strengthening of the local industry, the emergence of new lob opportunities and the development of new forms of entrepreneurial actions (European Communities, 2003). Especially, in the case of Italian South, a measure of the technological efficiency of southern businesses in comparison with those of the central-north is between 20 and the $30 \%$ less, while the difference in economic efficiency is between 8 and $10 \%$. The main reasons is that the southern enterprises occupy segments, market niches that permit them to survive but not to develop (Pennella, 2001). Furthermore, emphasis is placed on the promotion and support of co-operations with University and Research Institutions on specific projects (e.g. allocation of funds for research) [Srinivas and Viljamaa, 2007]. According to the Council of Competitiveness (1996:3), "the development of co-operations concerns the relationships forged among higher education institutions, government organizations and research laboratories aiming at the development and promotion of research". Especially important are the policies concerning the promotion and support of the creation of an attractive entrepreneurial environment whose objective is the development of new firms and the attraction of new ones. Building an attractive and dynamic entrepreneurial environment constitutes a very important factor for the reinforcement of urban development as the attraction of new firms and the maintenance of the existing ones is considered a prerequisite by regions and cities (Christiaans, 2002; Stubbs et al., 2002; Ulaga et al., 2002; ). For example, Pietrobelli 
and Rabellotti (2003) analyse the experience and the role of BDS Centres in three highly developed Italian regions, Emilia Romagna, Lombardia and Veneto, and evaluate their performance and contribution to the regional industrial, and notably SME, development. The study is especially relevant as these Centres have often been deemed responsible for the outstanding international competitiveness of Italian SMEs. In addition, the reinforcement and support of continuous training and life-long education is one of the basic principles of the E.U., highlighting, this way, the direct relationship between education and unemployment. Moreover, preparation and participation in the planning and implementation of specific strategic development plans or special marketing plans are a necessity in order for local authorities to support the total development and competitiveness of the cities they manage. Illustratively we mention the following: Strategic Plan for Prague (1999), Metropolitan Plan of Madrid (Jimenez-Moreno, 2001; Compitello, 2003), Glasgow and Bilbao (Gomez, 1998), Strategic Plan of Lisbon (Vasconcelos and Reis, 1997). Moreover, urban reforms and reconstructions of urban areas are actions with positive results for both urban development and competitiveness of firms which act in these cities (Beriatos and Gospodini, 2004; Adair et al., 2000; Seo, 2002). Furthermore, the quest of subsidies and contributory projects of the E.U. and participation in networks with other cities for information and experiences exchange, are actions which stimulate the economic profile of cities while, at the same time, contribute to the competitiveness of firms (European Commission, 2003; Cappellin, 2002). On the other hand, the monitoring, check and improvement of social and production infrastructures have a direct impact on the development of firms' actions. The existence of quality production infrastructures is a factor for the achievement of profitable entrepreneurial actions, contributing positively to the competitiveness of firms. If the case is not such, there are negative effects on the quality and quantity of the produced goods (International Labor Organisation-ILO, 1998).

In conclusion, we will support that the above policies are planned having as an objective the economic development and the competitiveness of regions where they are implemented, influencing positively the development and the actions of firms located in them. The most important fact is that the dynamic of success in the development of these policies is depending on all these groups which operate in the environment of the cities according to the substantial or not participation, the existence of a common vision and interest to the degree which is effective and the knowledge and experience on the design and implementation of development policies. The most interesting data shows the specific trends from firms that operate in the studied cities stressing the importance of the specific policies for local firms, the degree of effect to the use of this policies in the competitiveness of firms and the degree and kind of partnerships which are created by the firms and the development authorities and the groups of decision making. All the above are examined in the following sections. In table 1 the coding of these policies is presented.

\begin{tabular}{|lc|}
\hline \multicolumn{3}{|c|}{ Table 1: Development policies' codes } & Codes \\
\hline \multicolumn{1}{|c|}{ Development Policies } & P1 \\
\hline $\begin{array}{l}\text { Promotion of partnerships with private sector in specific development } \\
\text { projects }\end{array}$ & P2 \\
\hline Promotion of partnerships with Universities and Research Centres & P3 \\
\hline Promotion and support the creation of an attractive entrepreneurial &
\end{tabular}




\begin{tabular}{lc}
\hline environment & \\
\hline Enforcement the continuing learning and training process & P4 \\
\hline Participation on the planning and implementation of a city development plan & P5 \\
\hline Development of City Marketing Plan with specific aims and budget & P6 \\
\hline $\begin{array}{l}\text { Control of land use and promotion of regeneration and reconstruction of city } \\
\text { image }\end{array}$ & P7 \\
\hline Seeking for European Funds and programmes & P8 \\
\hline Participation in networks with other cities & P9 \\
\hline Control of the quality of production and social infrastructure & P10
\end{tabular}

\section{Some empirical evidence}

\subsection{Most important policies for firms (evaluation per sector)}

In figures 3a-3d the firms choices of the two cities $(n=183)$ per sector in reference with the importance of the development policies. This separation is important because these policies could be different per sector so it could be related with the orientation and design of these policies and activities in order to reinforce the development procedure with specific business sectors. The studied firms had to choose free from 5 to 10 developments polices as the most important for them. Also, these evaluations due to their origin which is local firms it's of high importance for the local economy and the competitiveness of the cities.

In the table 2a-2d it is important to pinpoint the following:

First there is a widespread and common evaluation of firms for the importance of policy P8. The participation of cities in European networks and programs targeting grants and a general dynamic presentation in European level is a significant gear/ factor of development for them as well as for the firms. There were sections with reference to activities and programs that the two cities participate which reinforce this evaluation. Critical is the fact that this policy is important for the firms that are established in two different political-economic and social environments. On one part, the firms of Varna which in terms of the integration and adjustment of Bulgaria consider the representation and participation to the European arena a crucial path for the development procedure and on another the firms of Bari in the region of Mezzogiorno which support the same attitude. In the opposite side the policy P7 is evaluated less important by all firms which don't consider as important the existence of a control mechanism for the land use through procedures of regeneration and reconstruction of city image. Similar with P7, low percentages seem to get policy $\mathrm{P} 4$. Issues of continuing vocational learning and training are not priorities for the studied firms. The opposite image leads to the conclusion that firms expect for the support of their economic dynamic and competitiveness through extrovert and international promotion and participation of their cities to European programs and development networks. This necessity is not new and contributes to the general effort of supporting SMEs especially in the Southeastern Europe the last 30 years(i.e. Loddo, 2004; Garofoli, 2002; Van Winden and Woets, 2003; Metaxas, 2008).

The second element of the tables is the changing evaluations of firms to the rest of the development policies according to their sector. For instance, policy P9 is evaluated 
as important mainly by industrial and tourist firms while in favor of P3 and P5 almost all firms were in favor with percentages over $40 \%$.

Especially, in the case of Italian environment, it's important to be mentioned that one of the first instruments that designed for the implementation of new business initiatives and the development of new jobs in industry, services and tourism was the Area Contract (Law 662/96). An evaluation of the effectiveness of this instrument in attracting foreign investment and enhancing specific competitive potentialities of Southern area is given in Bianchi and Mariotti (2002, cited in Loddo, 2004). Furthermore P1, is evaluated as important from $64,1 \%$ by the industrial firms while P6 by the tourist firms. It is apparent that the development of partnerships between public and private sector for the development of specific projects that enhance the local economy concerns the industrial firms. This evaluation is related with infrastructures projects for attracting new investments through a creation of an attractive business image of the studied areas and the reinforcement of the existed firms. In parallel, the design and development of plans and marketing activities shows that concern mainly the tourist sector which is expected.

Figures 3a, 3b, 3c, 3d: Development policies per firms sectors

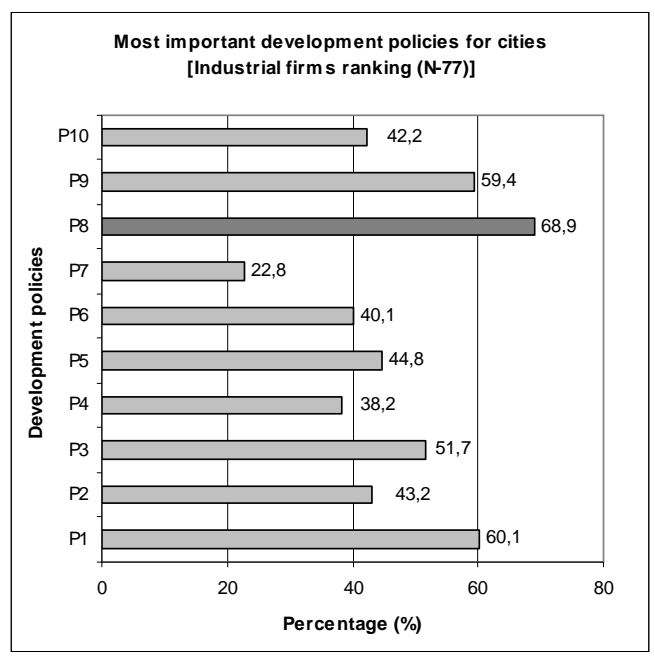

3a

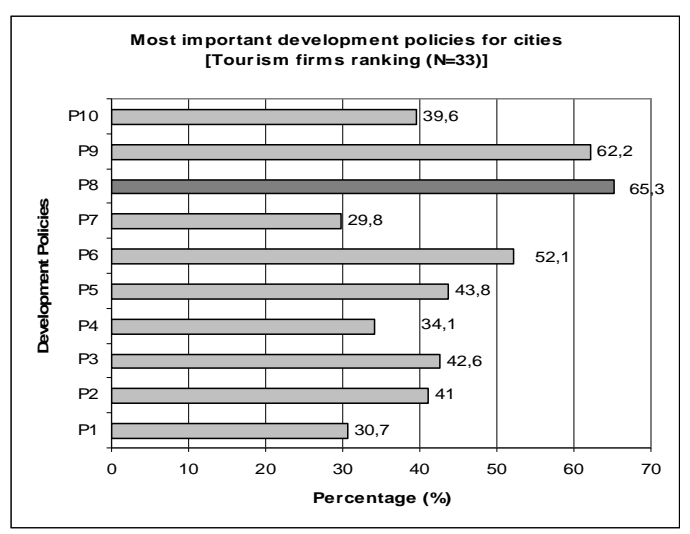

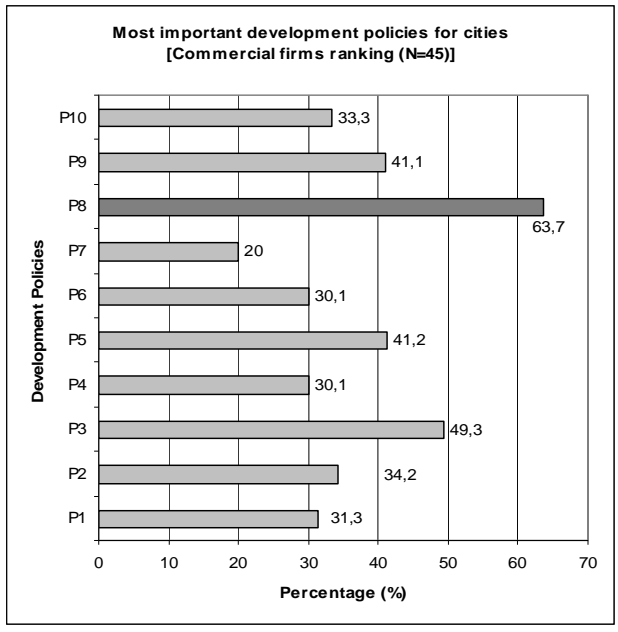

$3 \mathrm{~b}$

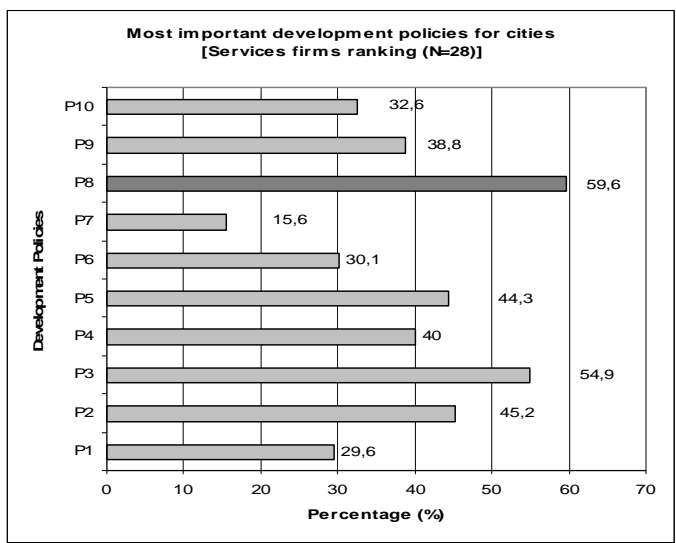


3c

Source: Author elaboration

\subsection{Most important policies for cities}

In figures $4 \mathrm{a}-4 \mathrm{~b}$ firms evaluate the importance of development policies for cities with goal the general development in local and regional level. The first image which is presented is important and concerns the participation percentages of firms in the two cities. The firms of Varna are more diffusing designating the importance of different policies. In the case of Bari there is a concentration of the firms' evaluation between 30 and 58 percentages. Most of the policies are evaluated as important except the policy P8. Finally, the firms of Bari adapt a rather conservative attitude related to the importance of development policies and to what extent these policies could affect the development of the broader region. Typical, this attitude could have an underlined concern about the design and effectiveness of these policies on local level. Nevertheless, this case could be false because the institution of Local Authorities is not new in Italy and they had an active role when it comes to design and implementation of polices (Piperno, 2000; Furre, 2007).

Figures 4a - 4b: Development policies for cities
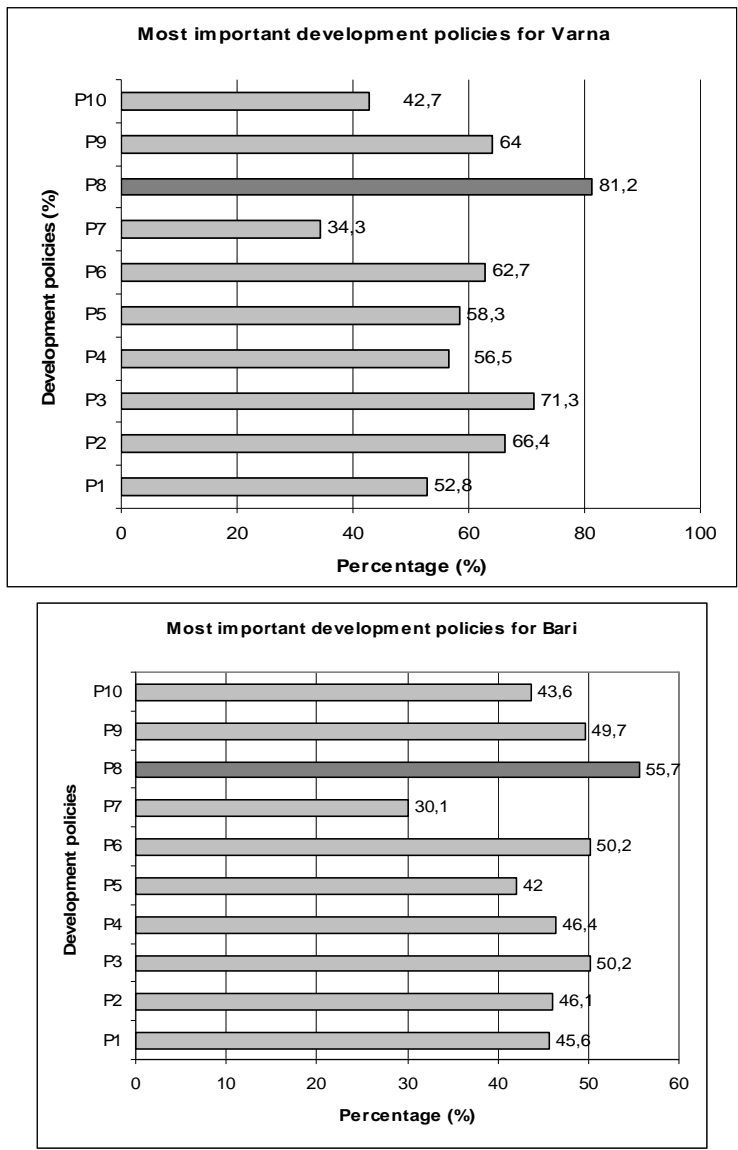

$4 \mathrm{a}$

More analytical, in tables $3 \mathrm{a}$ and $3 \mathrm{~b}$ the policy $\mathrm{P} 8$ is the most high rated by the firms of both cities especially Varna $(81,2 \%)$. Policy P3 which concern the creation 
and support of an attractive business climate for attracting foreign investments with Policy P6 which concern the appliance of city marketing plan seems to be a powerful tool for the development of the two cities according to the views of firms. Similar efforts have been recorded for both cities in the previous analysis. The only policy according to firms that is not important for the development and competitiveness of the studied cities is policy P7 which is referred as control of land use and promotion of regeneration and reconstruction of city image.

\subsection{Implementation of development}

The percentage of the studied firms that have developed specific development policies with local authorities is studied in this section. The main issues that are discussed are the following: First, the attitude of firms of the two cities when it comes to the idea and practice develop partnerships with local authorities. Second, the experience of firms in interworking for the development of specific policies and third, the exploration of the attitude of the firms for each city separately but also for the total firms.

More specific: In table 2 and in figure 5 there is a firm's distinction between the participation of firms in the development of partnerships with local authorities. The firms of Varna have developed in greater degree partnerships than firms of Bari. This fact is justified because Bulgaria is a new EU member and inexperienced in design and implementation of local development policies and competitiveness. From the other hand firms in Bari show a total absence of these partnerships expressing indirectly a total unease. The only orientation is the development of partnerships mostly in policies that concern learning and training programmes (P4) and European funding (P8) $(>70.0 \%)$. The total image form table 4 is that the studied firms have not developed partnerships with local authorities. The lack of trust in local authorities also the unease to policies that take place in local level could be the reasons for this image especially in the case of Bari.

Table 2: $\%$ of firms that implement development policies ( $\mathrm{n}=183)$

\begin{tabular}{|l|c|c|c|}
\hline \multicolumn{1}{|c|}{$\mathbf{D P}$} & Varna(n=87) & Bari (n=96) & \% and number of firms (n=183) \\
\hline P1 & 58,6 & 44,7 & $51,3(94)$ \\
\hline P2 & 32,1 & 28,1 & $30,0(55)$ \\
\hline P3 & 56,3 & 54,1 & $51,9(101)$ \\
\hline P4 & 55,1 & $\mathbf{7 3 , 9}$ & $70,9(119)$ \\
\hline P5 & $\mathbf{6 5 , 5}$ & 31,2 & $47,5(87)$ \\
\hline P6 & $\mathbf{6 6 , 6}$ & 40,6 & $53,0(97)$ \\
\hline P7 & 57,4 & 35,4 & $45,9(84)$ \\
\hline P8 & $\mathbf{6 0 , 9}$ & $\mathbf{7 1 , 8}$ & $66,6(122)$ \\
\hline P9 & 52,8 & 21,8 & $36,6(67)$ \\
\hline P10 & 41,3 & 20,8 & $30,6(56)$ \\
\hline$\%$ average & $\mathbf{5 3 , 2}$ & $\mathbf{3 9 , 7}$ & \\
\hline
\end{tabular}

Figure 5 


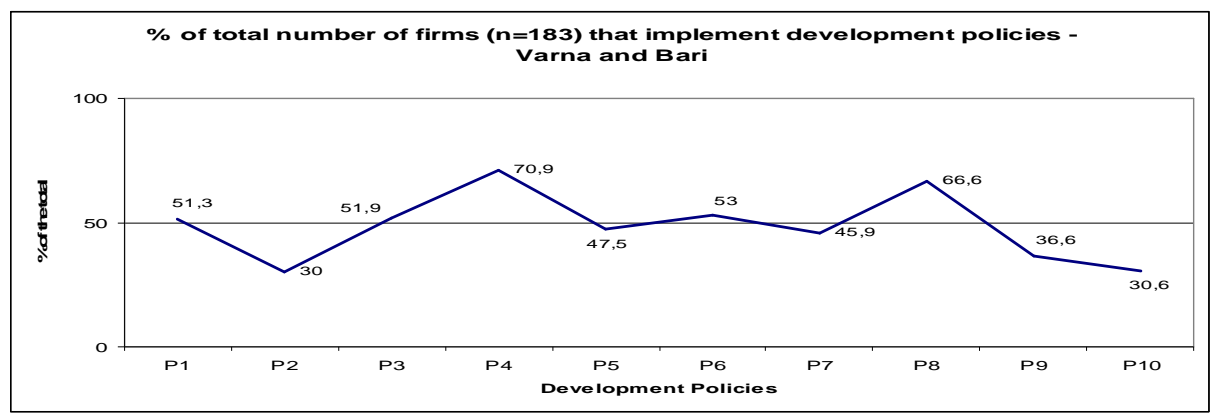

\subsection{Correlation of partnerships between local actors and development policies}

In table 3 is presented the how many firms have answered that had partnerships with local authorities and institutions. Specifically, certain conclusions come up:

First the degree of intensity of partnerships that have been developed the studied firms is low (17-L, 12-M and only 8-H). The most low and not regular partnerships were created with local and regional public administrations mostly for policies P3, P7 and P10 meaning the support the creation of an attractive entrepreneurial environment, the control of land use and promotion of regeneration and reconstruction of city image and the control of the quality of production and social infrastructure. The second important element is that most of the partnerships independent from the degree of intensity were developed form policies P3(8), P10(7) and P8(6). Meaning again that the support the creation of an attractive entrepreneurial environment, the control of the quality of production and social infrastructure and finally for European Funds and programmes. From the two elements the firms of the two cities seem to be interested in developing certain policies related with promotion, support and outward investment but also to issues of managing infrastructures but these partnerships are ineffective because they are not regular and strategically designed. The reason for this image is the lack of interest from the side of local authorities or from firms as a result of lack of trust to the ability of local authorities and the rest of the management authorities.

A third important conclusion is the combinations of regular partnerships with local authorities. These are few and oriented to certain policies and with specific authorities. In particular the high rated degree of partnerships happens with policies P1 (partnerships with private sector in specific development projects) where partnerships with business authorities dominate (business centers and chambers of industrial and commerce), P2 (partnerships with Universities and Research Centres) with similar authorities and P8 (investments and European programmes) with Universities and European organizations of Information. The final conclusion for the existence of partnerships firms set as a prerequisite the existence of knowhow and specialization. The above authorities are experts in the development of specific policies and firms content to trust these authorities and implement partnerships with them.

As a sequence to this the fourth conclusion of the analysis which distinguishes which local authorities have developed partnership with firms for the most development policies regardless the dynamic of these partnerships. It is obvious that Local Government, Local Development Agencies but also Business Centres and Chambers have implemented partnerships with firms for different development 
policies (more than 4 policies). The impact of these partnerships of the studied firms (positive or negative) comes from the relationships and partnerships with specific local authorities. Particular, Business Centers and the Chambers of Commerce and Industry have promoted partnerships with firms in policies of development projects (P1). In similar pattern, partnerships with Universities and Technical institutions have been promoted. Along with these universities and organizations for European issues have contacted partnerships related with funds from firms and participation to European programs (P8).To sum up the dynamic of these partnerships is small and oriented to specific policies. There is a gap between firms and local authorities because there is lack of maturity from both sides and there is a strong feeling from firms that local authorities lack in knowledge and ability when it comes to design and implement development policies in both cities.

Table 3: Partnerships that firm developed with particular local actors [level of partnership (H: high, M: Medium, L: Low)]

\begin{tabular}{|l|c|c|c|c|c|c|c|c|c|c|}
\hline \multicolumn{1}{|c|}{ Local Actors } & P1 & P2 & P3 & P4 & P5 & P6 & P7 & P8 & P9 & P10 \\
\hline Universities & & H & & L & & & & H & & L \\
\hline Technological Institutes & & H & & L & & & & & & M \\
\hline Business Centers & H & & H & & & L & & & L & M \\
\hline $\begin{array}{l}\text { Champers of Industrial and } \\
\text { Commerce }\end{array}$ & H & & M & & & L & & L & & L \\
\hline Local Government & L & & L & & M & L & L & M & & \\
\hline Regional Government & L & & L & & L & & L & & & \\
\hline Local Banks/ Financial Services & & & L & & & & & & & \\
\hline Local Development Agencies & M & & & & M & & & L & L & L \\
\hline $\begin{array}{l}\text { Local Promotional Offices/ } \\
\text { Marketing }\end{array}$ & & & M & & & M & L & & M & \\
\hline European Information Centers & & & M & & & & & H & L & L \\
\hline $\begin{array}{l}\text { Education \& continuing training } \\
\text { centers }\end{array}$ & & & & H & & & & & & \\
\hline Business incubators & & & L & & & & & & & L \\
\hline Local Politicians & & & & & & & L & M & & \\
\hline
\end{tabular}

\subsection{Development policies and enterprises' competitiveness (degree of influence)}

In table 4 the degree of the effect of the development policies to competitiveness of the studied firms is presented. Firms evaluate in a scale 1-10 which policies are related to their growth. This evaluation for each policy happens from those firms that believe that some policies concern them. The basic conclusions are:

First from the number of firms $(n=183)$ of both cities the policies that are related with the competitiveness of firms are P3, P4 and P8 (evaluated by over $>100$ $\varepsilon \pi \iota \varepsilon \varepsilon \rho \eta \sigma \varepsilon \omega v)$. The combination of these policies refers to the need of the studied firms and specific of Bari to create an attractive frame of strengthening the entrepreneurship of the areas along with supporting the firms from European funds and programs.

A second element is that firms of Varna in comparison than those of Bari do not consider strong some policies for their development. The averages are low while the standard deviations have low values which lead to the conclusion that this attitude concerns the total of firms in Varna. 
Finally, as far as P8 and P10 that concern European funds and check of social and productivity infrastructures. These policies for firms of Varna are considered meaningless in achieving competitiveness while the opposite happens with firms of Bari. A potential reason is that Bulgaria does not have the experience of strategic design and organization on local level of development but either the knowledge and exploitation of funding programs and resources from Europe which is an important issue after 2009.

Generally, based on the analysis, the importance of development policies means different things for firms of both cities. The meaning of these policies is recognized more in firms of Bari than Varna. Further this meaning is not catholic since a great number of firms of both cities do not relate competitiveness with development policies. This is obvious by the low percentages of firms' participation to this question for policies (eg P2 and P10 for all firms, P5 for Bari's firms, P8 for Varna's firms). This image is challenged as far as the dynamic of these policies concern and their implementation by local authorities.

Table 4. Degree of influence of development policies on firms' development

\begin{tabular}{|c|c|c|c|c|c|c|c|c|c|}
\hline & \multicolumn{4}{|c|}{ Varna } & \multicolumn{4}{|c|}{ Bari } & \\
\hline DP & $\mathbf{n}$ & AV & SD & $\begin{array}{c}\% \\
(87)\end{array}$ & $\mathbf{n}$ & AV & SD & $\begin{array}{l}\% \\
(96)\end{array}$ & $\begin{array}{l}\% \\
\text { (Total -183) }\end{array}$ \\
\hline P1 & 51 & 4,3 & 1,7 & 58,6 & 43 & 5,5 & 1,4 & 44,7 & $94(51,3)$ \\
\hline P2 & 28 & 3,5 & 1,1 & 32,1 & 27 & 5,6 & 1,5 & 28,1 & $45(24,5)$ \\
\hline P3 & 49 & 4,0 & 1,1 & 56,3 & 52 & 6,0 & 1,7 & 54,1 & $101(55,1)$ \\
\hline P4 & 48 & 4,2 & 1,2 & 55,1 & 71 & 6,2 & 1,3 & 73,9 & $119(65,0)$ \\
\hline P5 & 57 & 4,2 & 1,4 & 65,5 & 30 & 6,0 & 2,0 & 31,2 & $87(47,5)$ \\
\hline P6 & 58 & 4,2 & 1,3 & 66,6 & 39 & 5,6 & 1,6 & 40,6 & $97(53,0)$ \\
\hline P7 & 50 & 4,0 & 1,4 & 57,4 & 34 & 5,6 & 1,5 & 35,4 & $84(45,9)$ \\
\hline P8 & 53 & 3,9 & 1,4 & 60,9 & 69 & 6,3 & 1,5 & 71,8 & $122(66,6)$ \\
\hline P9 & 46 & 3,9 & 1,0 & 52,8 & 21 & 5,0 & 2,0 & 21,8 & $67(36,6)$ \\
\hline P10 & 36 & 3,5 & 1,0 & 41,3 & 20 & 6,6 & 1,8 & 20,8 & $56(30,6)$ \\
\hline $\mathbf{A V}$ & & 3,9 & 1,2 & & & 5,8 & 1,6 & & \\
\hline
\end{tabular}

\section{Conclusions}

The aim of this article was to designate the importance of certain policies for development of firms in two medium sized cities of Southeastern Europe, Varna in Bulgaria and Bari in Italy. The data of this research are based on empirical, primary data while the added value of this research is significant because it makes prominent the attitudes and evaluations of local firms on issues and policies of local economic development.

Some basic conclusions that arise are:

First, there is a strong element of question and discontent related with the ability of local authorities to design and implement development policies in order to enhance competitiveness and strengthen firms. This image comes in contrast with the efforts of the last 30 years to enhance competitiveness of SME firms of the European south. In the studied cases the places where these partnerships were developed were hypotonic while in issues of development of large projects, lifelong learning and training with seek European funds were strong.

A second important element is that the authorities involved in partnerships with

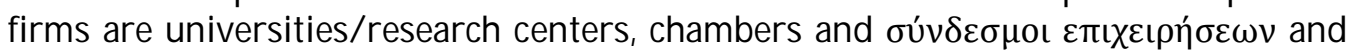


training centers. Yet, local and regional administrations, development companies and business incubators develop partnerships sporadically with small dynamic without contributing decisively to the growth and competitiveness of business environment.

Third, a major problem of local economic development rises under the responsibility of local authorities to use development policy. This problem becomes more intense when it comes to the less development European south where cities confront until today structural development problems for different reasons each one. This is translated as a specific approach in development locally with exploitation of competitive advantages orientated to endogenous characteristics targeting to strengthen the economic, productive and business base.

By ending the article supports that local development is the responsibility of local administration to a certain point. It is based on designation and implementation of specialized development policies through partnerships so that the added value of the whole development effort would be characterized as substantial and focused to the needed sectors.

\section{References}

Adair A., Berry J., McGreal S., Deddis B., Hirst, S. (2000), The financing of urban regeneration, Land Use Policy, 17(2), 147-156

Bagnasco A., Sabel, C.(eds) (1995), Small and Medium-size Enterprises. London: Pinter.

Barca F., Pellegrini, G. (2000) Politiche per la competitivita 'territoriale in Europa: note sul programma 2000- 2006 per il Mezzogiorno. Rome: Mimeo

Bennett R., Krebs G. (1991), Local Development Public-Private Partnerships Initiation in Britain and Germany, Belhaven Press, London, NY

Beriatos E., Gospodini A. (2004), Glocalising urban landscapes: Athens and the 2004 Olympics, Cities, 21(3), 187-202

Bianchi C. - Mariotti I. (2002) La delocalizzazione delle imprese italiane nel Mezzogiorno e nei paesi dell'Europa sud-orientale. Due sistemi in competizione? Rivista Economica del Mezzogiorno, 4, pp.745-794

Bibu, N.A. Sala, D. Pantea, M. and Bizoi, G. (2008), 'Considerations about the Influence Factors on the Competitiveness of SME's from Western Region of Romania', MPRA Paper, no.9479, July

Calafati G.A. (2005), From 'territory' to 'city': The conceptualisation of space in Italy since 1950, Quaderno di Ricerca n. 241, Università Politecnica delle Marche Dipartimento di Economia

Cantner, U. and Malerba, F. (2007), 'Innovation, Industrial Dynamics and Structural Transformation: Schumpeterian Legacies', Springer

Cantoro M. (2007), Themes on RDAs, Bilateral Cooperation Project, July, 2007

Cappelin R. (2002), Regional development in Italy and recent policy approaches to the development of Mezzogiorno, Paper presented at the Third Workshop April 15, 2002 University of Rome "Tor Vergata" Subgroup: "Market efficiency versus policy intervention" ARL-West European Working Group

Caporaso J., (1996) The European Union and forms of state: Westphalian, regulatory or postmodern?, Journal of Common Market Studies, vol. 34 (1), pp. 29-52

Cheshire, P.C. and Magrini, S. (1999), 'Evidence on the impact of territorially competitive policy and the role of transactions costs in conditioning collective (in) action', Research Papers in Environmental and Spatial Analysis, no.57 (dept. of Geography and Environment, London School of Economics)

Cheshire, P.C. and Magrini, S. (2001), 'Policies for urban growth, local public goods, spillovers and convergence/ divergence: some empirical and methodological answers', ESRC Cities programme 
Christiaans T. (2002), Regional Competition for the location of new facilities, The Annals of Regional Science, 36(4), 645-661

CITY DEVELOPMENT AUTHORITY OF PRAGUE (2000) Strategic Plan for Prague. Prague: City Development Authority.

Cochrane, A. and Jonas, A. (1999), 'Reimagining Berlin: World city, national capital or ordinary place?' European Urban and Regional Studies, 6(2):145-164

Compitello A.M. (2003), Designing Madrid, 1985-1997, Cities, 20 (6), 403- 411

CoR Studies E-1. (2004), Brussels, February, 2004

COUNCIL OF COMPETITIVENESS (2006) 'U.S Competitiveness 2001: Strengths, Vulnerabilities and Long-term Priorities', Council of Competitiveness, Washington, DC

Crossa, V. (2009), "Resisting the entrepreneurial city: street vendors $\dot{c}$ struggles in Mexico City's Historic Center". International Journal of Urban and Regional Research, Vol.33-1, 43-63

Daniele V. (2009), Regional convergence and public spending in Italy. Is there a correlation?, MPRA Paper No. 14334, posted 29. March 2009

D’Antonio M., Colaizzo R., Leonello G. (1988), Mezzogiorno/ Centre-North: A Two-Region model for the Italian Economy, Journal of Policy Modeling, 10(3), 437-451

Dekker, K. and van Kempen, R. (2004), "Urban governance within the Big Cities Policy: Ideals and practice in Den Haag, the Netherlands", Cities, Vol.21, No.2, pp.109-117

De Rooij R., (2002) The impact of the European Union on local government in the

Netherlands' Journal of European Public Policy, vol.9 (3), pp.447-467

Diamantini C., and Geneletti, D. (2004), Reviewing the Application of Sea to Sectoral Plans in Italy. The case of the Mobility Plan of an Alpine region, European Environment, 14(2), 123-133

Dicken, P. Forsgren, M. and Malmberg, A.I. (1994), "The local embeddedness of transational corporations", in Hudson R., 2002, "Global Production Systems and European Integration", Working Paper, No. 43, University of Durham

Driscoll, J. (2002), 'Introducing Community Based Capital Investment Planning in Bulgaria', LGI, December 2002, Sofia

Eriksen O.E. (2004) 'Reflexive integration in Europe', ARENA Working Paper, no. 20, Uni. Oslo

EUROPEAN COMMISSION (2003), 'Structural policies and European territories: Competitiveness, sustainable development and cohesion in Europe. From Lisbon to Gothenburg', Luxembourg: Office for Official Publications of the European Communities

European Urban Knowledge Network, (2009), URBAN II MOLA DI BARI. Enhancement of the cooperation between institution and social groups to promote the socio-economic regeneration Mola di Bari, IT

Fuller C., Bennett J.R., and Ramsden M. (2003), Organising for inward investments? Development agencies, local government and firms in the inward investment process, Environment and Planning A, 35(11), 2025-2051

Garofoli G. (1989), Industrial districts: structure and transformation,Econ. Notes,18(1),37-54.

Getimis P., Grigoriadou D. (2004) "The Europeanization of urban governance in Greece: a dynamic and contradictory process" International Planning Studies, 9(1): 5-25

Giacchero, A. Donnini, N. and Martin, F. (2007), 'Innovation and Competitiveness in SMEs: Characteristics of firms, entrepreneurs, environment and their interrelationships', in Cantner, U. and Malerba F. eds, "Innovation, Industrial Dynamics and Structural Transformation: Schumpeterian Legacies", Springer, pp. 173-188

Gomez M.V. (1998), Reflective images: The case of urban regeneration in Glasgow and Bilbao, International Journal of Urban and Regional Research, 22(1), 106-121

Hagerdoom, J. Link, N.A. and S.N. Vorontas, S.N. (2000), 'Research Partnerships', Research Policy, Vol. 29, 567-586

Hall T., and Hubbard P. (1998), The Entrepreneurial city, J. Wiley and Sons, eds.

Harrighton J.W., Warf B. (1995), Industrial Location, Principles, Practice and Policies, Routledge, London

Harvey D., (1989), The Condition of Postmodernity', eds Blackwell, Oxford 
International Labour Organisation (ILO) (1998), 'Local Economic Development Agencies as an instrument to promote job-creation in Europe', ILO, Employment sector

Kapitanova, G. and Minis, P.H. (2003), 'Case study of Bulgaria: From Totalitarianism to Democratic Local Governance', Local Government Initiative

Kresl K. P., Singh B. (1999), Competitiveness and the Urban Economy: Twenty-four large US metropolitan areas, Urban Studies, 36 (5-6), 1017-1027

Local Government Initiative, (2003), 'Small cities capacity building strategy', National Association of Municipalities of the Republic of Bulgaria and Club Economica 2000', May 2003

Loddo S. (2004), Old and new intervention policy: A survey of empirical studies for the Mezzogiorno, Working Paper, no.1, Università di Cagliari e CRENoS

Magrassi M. (1994), Development Funding as a Catalyst for Urban Reform in Southern Italy, DISP, 158, 27-33

Marks G., and McAdam D., (1996) 'Social movements and the changing structure of political

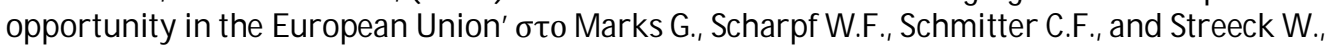
(eds), Governance in the European Union, London: Sage Publications, pp. 95-120

Metaxas T. (2008) "Attractive investment images in Southeastern Europe: The case of Varna, Bulgaria'. SEE Journal of Economics and Business, 1.3, 59-76

Metaxas, T. (2010), "Place Marketing, place branding and Place marketing, place branding and foreign direct investments: Defining their relationship in the frame of local economic development process", Place Branding and Public Diplomacy, Vol.6, No.3, pp. 228-243.

Metaxas, T. (2011a), Shaping the image of Bulgaria as FDI destination in Southeastern Europe: The course after 1989', Applied Econometrics and International Development, vol. 11(2):51-70

Metaxas, T. (2011b), Territorial Assets and Firms' Competitiveness In Southern Europe: Industrial Vs Commercial Firms Using Exploratory Factor Analysis', Regional and Sectoral Economic Studies, vol. 11(1): 45-62

Metaxas T., and Kallioras D. (2007), “Cities' economic development and regional competitiveness: the case of Larissa-Volos dipole in Thessaly region", Review of Economic Sciences, Vol.12, pp. 115-136.

Moreno-Jimenez A. (2001), Interurban shopping, new town planning and local development in Madrid metropolitan area, Journal of Retailing and Consumer services, 8(5), 291-298

Pacione M. (1976), Development policy in Southern Italy Panacea or polemic?, Tijdschrift voor Econ. en Soc. Geografie, 67(1), 38-47

Pennella, G. (2001). Mezzogiorno Ondivago - The swaying south: Southern Italy from "question" to "opportunity". The Catholic University of America, Department of Politics. Retrieved

http:/ / unpan1.un.org/ intradoc/ groups/ public/ documents/ CAIMED/ UNPAN011115.pdf

Pereira, P.O. and Coutinho, M. (2011) 'Vitality and requalification of cities: a contribution to a reconceptualization of a sustainable urban planning', Regional and Sectoral Economic Studies, 11(2): 83-98

Piperno S. (2004) Fiscal dissentralisation in Italy: Some lessons, Italy, Ministry of Finance (1 $1^{\text {st }}$ draft)

Pietrobelli, C. and Rabellotti, R (2003) 'Business Development Service Centres in Italy: Close to firms, far from innovation' Paper presented at the RSA Conference Pisa, $12^{\text {th }}-15^{\text {th }}$ April 2003

Polidano C. (2000), Measuring Public Sector Capacity, World Development, 28(5), 805-822

Priemus, H. (2002), 'Public-Private Partnerships for Spatio-economic Investments: A changing spatial planning approach in the Netherlands', Planning Practice and Research, Vol.17 (2), 197-203

RIMED, (2005), "Regional Integration and Metropolitan Development in Southeastern Europe: Final Report", Volos: University of Thessaly Press

Rossi U. (2004), "New Regionalism contested: some remarks in light of the case of the Mezzogiorno of Italy", International Journal of Urban and Regional Research, 28, 2, pp. 466-476 
Santos Cumplido, Francisco Javier \& Liñán Alcalde, Francisco, 2002. "Towards an empirical methodology for the measurement of the quality entrepreneur: the case of sevillian entrepreneurs," ERSA conference papers ersa02p180, European Regional Science Association.

Scott, C., Reid, M., Yeabsley, J., and Zollner, E. (2004), 'Local Government's role in Strategic Policy and Planning', Victoria University of Wellington (www.localfutures.ac.nz)

Sellgren, J. (1990), "Local economic development partnerships - An assessment of local authority economic development initiatives", Local Government Studies, Vol.16, No.4, pp.57-78

Seo J-K. (2002), Re-urbanisation in Regenerated Areas of Manchester and Glasgow, Cities, 19 (2), 113-121

Smallbone, D. (1991), "Partnership in Economic Development: The Case of U.K. Local Enterprise Agencies", Policy Studies Review, Spring/ Summer, Vol.10, No.2/ 3, pp. 87-98

Stathakopoulos V. (2005), Market Research Methods, Stamoulis Eds., Athens

Strange, I. (1997), "Directing the show? Business leaders, local partnership, and economic regeneration in Sheffield", Environment and Planning C: Government and Policy, Vol.15, No.1, pp.1-17

Stubbs B., Warnaby G., Medway D. (2002), Marketing at the public/ private sector interface; town centre management schemes in the south of England, Cities, 19(5), 317-326

Srinivas, S and Viljamaa, K. (2007). "Emergence of Economic Institutions: Analysing the Third Role of Universities in Turku, Finland," Regional Studies, vol. 42(3), pages 323-341.

Tsenkova, S. (2004), 'Post-socialist cities in a globalised world', University of Calgary, Faculty of Environmental design, Canada

Ulaga W., Sharma A., Krishnan R. (2002), Plant location and place marketing: understanding the process from the business customer's perspective, Industrial Marketing Management, 31, 393-401

van den Berg, L. and Braun, E. (1999), 'Urban competitiveness, Marketing and the need for Organizing capacity', Urban Studies, Vol. 36(5-6), 987-999

van den Berg, L., van der Meer, J., and Pol, M. J., (2003), Organizing capacity and social policies in European cities, Urban Studies, 40(1), 1959-1978

van den Berg, L., Braun, E., and van der Meer, J., (1997), The organizing capacity of metropolitan regions, Environment and Planning C: Government and Policy, 15, pp. 253-272

van Winden W., Woets P. (2003), Local Strategic Networks and Policies and ICT Clusters: The Cases of Amsterdam, Bari, Dublin and Oulu, Paper prepared for the 15th Annual Conference of the European Association for Evolutionary Political Economy, Maastricht, The Netherlands, 7th 10th November 2003

Vasconcelos L T., Reis, A. C. (1997), Building new institutions for Strategic Planning: Transforming Lisbon into the Atlantic capital of Europe' in Healy P, Khakee, A, Motte A, Needham B, 1997 'Making Strategic Spatial Plans: Innovation in Europe', ch. 6, UCL, Press

Viesti G. (2002), Economic Policies and Local Development: Some Reflections, European Planning Studies, 10(4), 467-481

Wallis, J. and Dollery, B. (2002), 'Local Government Capacity and Social Capital', Economic Discussion Papers, no. 0207, University of Ottago, New Zealand

Warren M.R. (1994), Exploitation or Cooperation? The Political Basis of Regional Variation in the Italian Informal Economy, Politics and Society, 22 (1), 89-115.

Waters S. (1999), Chambers of Commerce in Italy: A Model of corporative development?, European Urban and Regional Studies, 6(2), 115-126

Williams, M.P. (2002), 'Community Strategies: Mainstreaming Sustainable Development and Strategic Planning?. Sustainable Development, vol. 10, 197-205

Worrall, L., Collinge, C. and Bill, T. (1998) 'Managing strategy in local government', International Journal of Public Sector Management, 11(6): 472-493

Revista Galega de Economia/ Economic Review of Galicia: ttps:/ / ideas.repec.org/ s/ sdo/ regaechtml http:/ / www.usc.es/ econo/ RGE/ benvidag.htm 
